Invited review

\title{
BDNF and memory processing
}

\author{
Pedro Bekinschtein ${ }^{\mathrm{a}}$, Martin Cammarota ${ }^{\mathrm{b}}$, Jorge H. Medina ${ }^{\mathrm{a}, \mathrm{c}, *}$ \\ a Instituto de Biologia Celular y Neurociencias, Facultad de Medicina, UBA, Argentina \\ b Instituto do Cérebro, Universidade Federal do Rio Grande do Norte, Av. Nascimento de Castro 2155, RN59056-450 Natal, Brazil \\ ${ }^{\mathrm{c}}$ Departmento de Fisiologia, Facultad de Medicina, UBA, Paraguay 2155, 1121 Buenos Aires, Argentina
}

\section{A R T I C L E I N F O}

\section{Article history:}

Received 16 January 2013

Received in revised form

14 March 2013

Accepted 8 April 2013

\section{Keywords:}

Long-term memory

Memory persistence

Hippocampus

Prefrontal cortex

Neurotrophins

\begin{abstract}
A B S T R A C T
Brain-derived neurotrophic factor has emerged as one of the most important molecules involved in memory. Its wide role in different types of memories that depend on different structures as well as its involvement in distinct memory stages points at BDNF as one likely target to treat cognitive impairments and anxiety-related memory disorders. However, regulation of BDNF expression is very complex as well as its modes of action. Here we describe the latest research carried out on the function of BDNF in memory to illustrate such complexity.

This article is part of the Special Issue entitled 'BDNF Regulation of Synaptic Structure, Function, and Plasticity'.
\end{abstract}

(c) 2013 Elsevier Ltd. All rights reserved.
The neurotrophin BDNF (brain-derived neurotrophic factor) is a member of a family of neurotrophic factors critically involved in regulating the survival and differentiation of neuronal populations during development (Huang and Reichardt, 2001). A great body of evidence indicates also that BDNF regulates the structure and functions of different neuronal circuits throughout life (Poo, 2001; Tyler et al., 2002; Lu et al., 2009). In the last 15 years attention has been focused to demonstrate the role of BDNF and its precursor pro-BDNF in activity-dependent synaptic plasticity (Bramham and Messaudi, 2005; Kuczewski et al., 2010; Lu et al., 2008; Poo, 2001; Tyler et al., 2002). Consistent with the view that activity-dependent changes in synaptic strength underlie memory processing and storage (Kandel, 2001), a growing body of evidence emerged suggesting that BDNF plays a crucial role in learning and memory (Tyler et al., 2002; Pang and Lu, 2004). Because of the number of excellent reviews on different aspects of the neurobiology of BDNF (Bramham, 2008; Cunha et al., 2010; Greenberg et al., 2009; Huang and Reichardt, 2003; Kuczewski et al., 2010; Lu et al., 2008; Minichiello, 2009; Murer et al., 2001; Pang and Lu, 2004; Rattiner et al., 2005; Tyler et al., 2002), here we focus on the role of BDNF in learning and memory, and especially on an emerging set of studies published in the last 5 years that examined further the role of BDNF in memory processing (Table 1 ).

\footnotetext{
* Corresponding author. Instituto de Biologia Celular y Neurociencias, Facultad de Medicina, UBA, Paraguay 2155, 1121 Buenos Aires, Argentina. Tel.: +54 11 45083854.

E-mail address: jmedina@fmed.uba.ar (J.H. Medina).
}

\section{Role and mechanisms of BDNF in memory formation}

Given that memory is not a unitary process but has several different phases or stages (acquisition, short-term memory, longterm memory (LTM) formation and consolidation, maintenance, retrieval, extinction, reconsolidation) we will discuss on the role of BDNF in all these stages in different learning tasks whenever the information is available.

Most if not all the roles of BDNF in the CNS depend on the interaction of BDNF with two different transmembrane receptors localized to dendrites, axons and soma of excitatory and inhibitory neurons: 1 - the tropomyosin-related kinase $B(\operatorname{TrkB})$ receptor which is responsible for the majority of the known functions of BDNF; 2 - the pan neurotrophin p $75^{\text {NTR }}$ which is probably the receptor that interacts with the precursor proBDNF. BDNF is secreted both pre or postsynaptically (see for references Kuczewski et al., 2010 ) in an activity-dependent manner as a mixture of its precursor proBDNF and mature BDNF (Pang and Lu, 2004).

BDNF binds to TrkB triggering the activation of one or more of three major signaling pathways involving phosphatidylinositol 3-kinase (PI3K), phospholipase C gamma (PLC-gamma) and extracellular signal-regulated kinase $1 / 2$ (ERK1/2) (Huang and Reichardt, 2003). In addition, it has been recently found that upon BDNF binding, TrkB undergoes serine phosphorylation by CdK5 (Lai et al., 2012), which appears to be important for normal learning. BDNF is a key mediator of memory processing by means of its effects on different molecular levels: it regulates cation channels including several subtypes of $\mathrm{Na}^{+}$and $\mathrm{K}^{+}$channels; it also modulates ligand- 
Table 1

BDNF in neuronal plasticity and memory processing - literature highlights.

\begin{tabular}{|c|c|}
\hline $\begin{array}{l}\text { Dragunow M. et al., Neurosci. Lett. } 1993 \text { 160:232-6 } \\
\text { Castrén E. et al., Neuroreport. } 1993 \text { 4:895-8 }\end{array}$ & $\begin{array}{l}\text { Almost simultaneously, these papers provided the first demonstration that LTP induction at } \\
\text { perforant path-dentate cells synapses induces the NMDAr-dependent expression of BDNF }\end{array}$ \\
\hline Kang H. and Schuman E.M. Science. 1995 267:1658-62 & Showed that exogenous BDNF is able to potentiate Schaffer collateral-CA1 synapses \\
\hline Ma Y.L. et al., Neuroscience. 1998 82:957-67 & $\begin{array}{l}\text { Demonstrated that pre-training inhibition of BDNF expression in the hippocampus hinders } \\
\text { avoidance memory }\end{array}$ \\
\hline Linnarsson S. et al., Eur. J. Neurosci. 1997 9:2581-7 & First demonstration the BDNF-mutant mice show impaired spatial memory \\
\hline Kesslak J.P. et al., Behav. Neurosci. 1998 112:1012-9. & This paper was the first to show that learning increases BDNF expression in the hippocampus \\
\hline Johnston A.N. et al., Neuroscience. 1999 88:1033-42 & $\begin{array}{l}\text { Using function-blocking anti-BDNF antibodies this work demonstrated that the involvement } \\
\text { of BDNF in memory processing is not restricted to mammals. }\end{array}$ \\
\hline Tokuyama et al., Nat. Neurosci. 2000 3:1134-42 & $\begin{array}{l}\text { Using PCR-based mRNA quantitation and in situ hybridization this was the first work to } \\
\text { demonstrate that cortical BDNF is involved in declarative memory processing in primates }\end{array}$ \\
\hline Rattiner L.M. et al., J. Neurosci. 2004 24:4796-806 & In these two papers, Rattiner and coworkers described for the first time a role for BDNF and \\
\hline Rattiner L.M. et al., Learn Mem. 2004 11:727-31 & $\begin{array}{l}\text { TrkB in amygdala-dependent learning and provided direct evidence of differential BDNF promoter } \\
\text { usage during memory formation }\end{array}$ \\
\hline Pang et al., Science. 2004 306:487-91 & $\begin{array}{l}\text { In this seminal work, Bai Lu's group demonstrated that BDNF maturation is essential for LTP in the } \\
\text { hippocampus, and reported that application of exogenous BDNF is sufficient to rescue LTP when } \\
\text { protein synthesis is inhibited, indicating that BDNF is not only necessary but sufficient for the } \\
\text { expression of synaptic potentiation. }\end{array}$ \\
\hline Heldt S.A. et al., Mol Psychiatry. 2007 12:656-70 & First report showing the involvement of BDNF in memory extinction. \\
\hline Bekinschtein P. et al., Neuron. 2007 53:261-77 & $\begin{array}{l}\text { This paper demonstrated that hippocampal BDNF is essential not only for consolidation but also } \\
\text { for persistent storage of long-term fear memory. }\end{array}$ \\
\hline Barnes P. and Thomas K.L. PLoS One. 2008 3:e3248 & $\begin{array}{l}\text { In this work, Barnes and Thomas showed that BDNF maturation in the hippocampus is crucial } \\
\text { for acquisition and extinction of fear memory. }\end{array}$ \\
\hline Peters j. et al., Science. 2010 Jun 4; 328(5983):1288-90 & $\begin{array}{l}\text { In this highly influential paper, the group of Gregory Quirk reported that, when infused into the } \\
\text { mPFC of rats previously submitted to auditory fear conditioned, BDNF reduces expression of the } \\
\text { learned fear response even in the absence of extinction training, suggesting that BDNF is capable } \\
\text { of substituting for extinction. }\end{array}$ \\
\hline
\end{tabular}

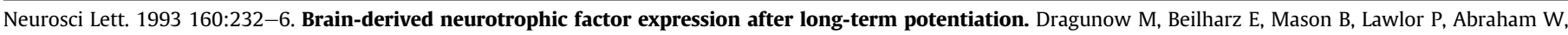
Gluckman P.

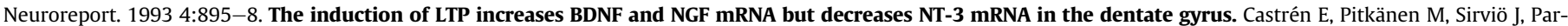
sadanian A, Lindholm D, Thoenen H, Riekkinen PJ.

Science. 1995 267:1658-62. Long-lasting neurotrophin-induced enhancement of synaptic transmission in the adult hippocampus. Kang H, Schuman EM.

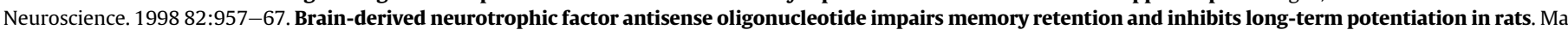
YL, Wang HL, Wu HC, Wei CL, Lee EH.

Eur J Neurosci. 1997 9:2581-7. Learning deficit in BDNF mutant mice. Linnarsson S, Björklund A, Ernfors P.

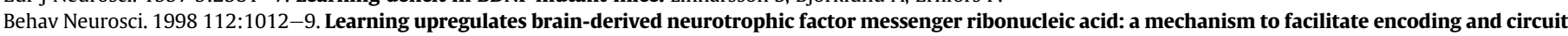
maintenance? Kesslak JP, So V, Choi J, Cotman CW, Gomez-Pinilla F.

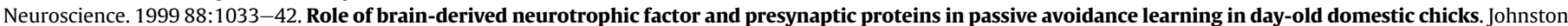
AN, Clements MP, Rose SP.

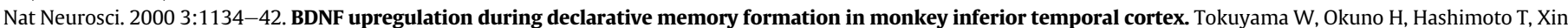
Li Y, Miyashita Y.

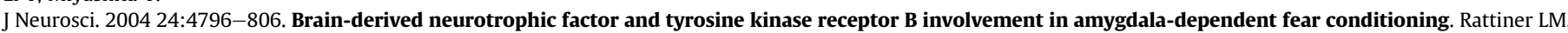
Davis M, French CT, Ressler KJ.

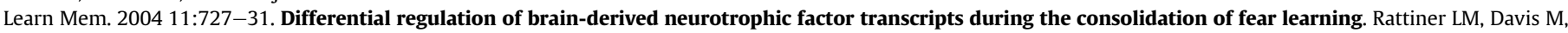
Ressler KJ.

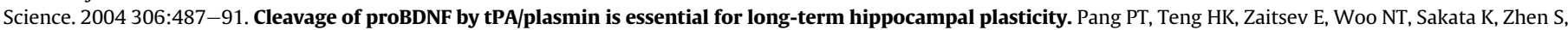
Teng KK, Yung WH, Hempstead BL, Lu B.

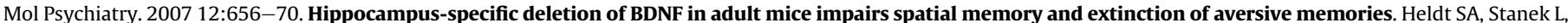
Chhatwal JP, Ressler KJ.

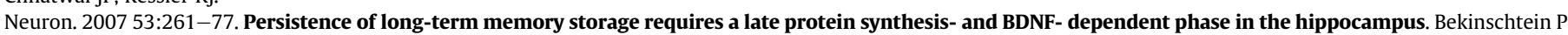
Cammarota M, Igaz LM, Bevilaqua LR, Izquierdo I, Medina JH.

PLoS One. 2008 3:e3248. Proteolysis of proBDNF is a key regulator in the formation of memory. Barnes $\mathrm{P}$, Thomas KL.

Science. 2010 328:1288-90. Induction of fear extinction with hippocampal-infralimbic BDNF. Peters J, Dieppa-Perea LM, Melendez LM, Quirk GJ.

gated channels like NMDA and AMPA receptors (see Cunha et al., 2010) and greatly affects protein synthesis by transcriptional and translational mechanisms. Different signaling pathways mediate transcription regulation by BDNF. Exposure of hippocampal slices to BDNF elicits a rapid increase in the phosphorylation state of CREB at Ser 133, the transcriptional regulatory site of CREB, increasing the expression of many genes including c-fos, egr- 1 , and nNos (Riccio et al., 2006), via activation of the ERK cascade (Arthur et al., 2004; Bozon et al., 2003). BDNF also induces serum response factor (SRF)-mediated transcription (Kalita et al., 2006) targeting SRE through the ERK-Elk1 signaling pathway (Bozon et al., 2003; Ramanan et al., 2005). Interestingly, the lack of SRF abolishes activity-dependent c-fos, egr-1 and Arc expression in the hippocampus (Ramanan et al., 2005). Activation of PI3K leading to CaMKII phosphorylation is also involved in BDNF-mediated gene expression in the brain. Translational regulation by BDNF is mainly due to the ability of BDNF to potently activate mammalian target of rapamycin (mTOR) and ERK cascades, both of which are important regulators of global and local translation (Kelleher et al., 2004). By using high throughput proteomics, it has been demonstrated that BDNF increases the synthesis of a wide variety of synaptic and translation machinery proteins in synaptoneurosomes, suggesting that BDNF may also enhance the translational capacity at synapses (Liao et al., 2007). These findings also support previous results showing that BDNF controls the local synthesis of several plasticityrelated proteins including $\alpha$ CaMKII, Arc, homer 2 and GluR1 (Schratt et al., 2004; Slipczuk et al., 2009; Yin et al., 2002).

\section{Hippocampus and/or amygdala-dependent memory processing}

Several hippocampus and/or amygdala-dependent learning tasks, including fear extinction, are accompanied by specific changes in BDNF mRNA and protein processing, requiring optimal 
levels of endogenous BDNF to form stable memories. For example, recognition memory increases BDNF release and activates ERK2 in the dentate gyrus and the perirhinal cortex (Callaghan and Kelly, 2012). We found that post-training intra-CA1 infusion of function-blocking anti-BDNF antibodies hampers object recognition memory retention, whereas object recognition training increases CA1 BDNF levels in a nNOS- and $\beta$-adrenergic receptordependent manner (Furini et al., 2010). In this respect, it has been reported that hippocampal-specific deletion of the BDNF gene impairs novel object recognition as well as spatial learning in the water maze (Heldt et al., 2007).

Contextual fear learning induces differential regulation of exonspecific BDNF mRNAs (I, IV, VI, IX) that is associated with changes in BDNF DNA methylation (Lubin et al., 2008; for a comprehensive review on the epigenetics of the BDNF gene and its involvement in memory formation see Lubin, 2011). Encoding of contextual fear conditioning is also associated with increased proteolysis of proBDNF (Barnes and Thomas, 2008). Interfering with BDNF signaling in the amygdala profoundly affects acquisition and consolidation of fear conditioning (Mahan and Ressler, 2012). Endogenous BDNF in the hippocampus (Heldt et al., 2007) and amygdala (Kirtley and Thomas, 2010) appears to be necessary for extinction of aversive/fear memories and gates in the amygdala the exclusive induction of extinction. Recently, it has been demonstrated that BDNF overexpression in the basolateral amygdala decreases freezing in the fear renewal test suggesting that it regulates fear memory erasure (Karpova et al., 2011). An increase in BDNF expression and in the phosphorylation state of TrkB in the central nucleus of the amygdala accompanies conditioned taste aversion training (CTA), while infusion of function blocking anti-BDNF antibody or antisense BDNF oligonucleotides into this nucleus impairs short-term memory (STM)- and LTM retention of CTA (Ma et al., 2011).

What are the downstream components of the BDNF-driven signaling pathway involved in memory consolidation? BDNF has been shown to exert its effects on neuronal plasticity through different signaling pathways (see above). For example, acute application of exogenous BDNF induces a form of potentiation (BDNF-LTP) that closely resembles LTP in CA1 acute mini slices, in neurons in culture (Kang and Schuman, 1995; Korte et al., 1995) and in vivo (Ying et al., 2002). Like theta-burst stimulation late LTP, BDNF-LTP requires rapid ERK1/2 activation and gene expression (Soule et al., 2006; Ying et al., 2002). Consistent with these findings, BDNF facilitates the induction of ERK-dependent long-term facilitation in Aplysia (Sharma et al., 2006). Experiments performed using inhibitory avoidance (IA) learning showed that inhibition of ERK1/2 signaling 15 min before or $3 \mathrm{~h}$ after training impairs LTM retention (Alonso et al., 2002; Bekinschtein et al., 2008). In addition, injection of functionblocking anti-BDNF antibody in dorsal CA1 $5 \mathrm{~min}$ before and 1 or $4 \mathrm{~h}$ after training produces amnesia for IA learning 24 and $48 \mathrm{~h}$ after acquisition (Alonso et al., 2002; Bekinschtein et al., 2007). Although these results do not establish a direct link between BDNF and ERK1/2 during memory consolidation, they provide support for a possible role of this signaling cascade in BDNFdependent memory consolidation.

Little is known about the functional role of BDNF in STM. Consistent with the findings that BDNF has rapid effects on neuronal excitability that are independent of macromolecular synthesis (see above), Alonso et al. (2002) have shown that inhibition of BDNF at the moment of IA training causes STM impairment when evaluated $1.5 \mathrm{~h}$ after training. Inhibition of ERK1/2 at the moment of training also causes amnesia for IA STM, suggesting a role for ERK1/2 pathway as an effector of rapid protein-synthesis independent BDNF signaling.
Another study using IA learning was among the first ones to demonstrate a direct link between BDNF and mTOR in memory consolidation (Slipczuk et al., 2009). In this work, IA training was associated with two time windows of mTOR activation in the hippocampus, the first one around the moment of training and the second one $3 \mathrm{~h}$ posttraining. In agreement with these results, injection of rapamycin 15 min before or $3 \mathrm{~h}$ after training, but not at other post-training time points, caused a profound LTM impairment. Importantly, administration of BDNF-blocking antibody 15 min before or $2.45 \mathrm{~h}$ after training prevents mTOR activation immediately post-training or $3 \mathrm{~h}$ thereafter. Although both posttraining time windows share the same signaling mechanisms, the source for BDNF seems to be different. While the function-blocking antibody produces amnesia 15 min before or $3 \mathrm{~h}$ after training, preventing BDNF expression, BDNF antisense oligonucleotides only impairs LTM when injected $1 \mathrm{~h}$ posttraining. This suggests that while BDNF activates mTOR early and late after training, already synthesized BDNF is used during the first time window and newly synthesized BDNF is required for the second one.

Two recent papers shed some light about one unexpected candidate for a downstream component of BDNF signaling pathways: PKMzeta. This atypical PKC isoform is persistently activated during L-LTP (Sacktor et al., 1993) and was repeatedly suggested to be involved in maintenance of memory storage (Sacktor, 2011). One of above mentioned studies showed that BDNF sustains L-LTP through PKMzeta in the CA1 region of the hippocampus (Mei et al., 2011) and the other demonstrated that BDNF is linked to PKMzeta in modulating memory consolidation of a spatial learning task (Adasme et al., 2011). However, the role of PKMzeta in memory has been recently challenged by two studies in which they failed to find any memory deficit in PKMzeta deficient mice (Lee et al., 2013; Volk et al., 2013).

\section{Cortex-dependent memory processing}

Deletion of BDNF gene in specific neocortical areas revealed that prelimbic BDNF is required for consolidation of fear memory, but not for the expression of innate fear (Choi et al., 2010). Moreover, the putative agonist of $\operatorname{TrkB} 7,8$ dihydroxiflavone (7,8 DHF) rescued the deficits in learned fear memory. However, in Carf knock-out mice, which haveselectively reduced expression of Bdnf exon IVcontaining mRNA transcripts and BDNF protein in the cerebral cortex, there is no alteration in fear memory consolidation; instead, these animals show impaired memory extinction (McDowell et al., 2010). Indeed, BDNF infusion into the infralimbic portion of the medial prefrontal cortex facilitates extinction of auditory fear conditioning and, even in the absence of behavioral extinction training, BDNF reduces fear, suggesting that this neurotrophin is able to substitute for extinction (Peters et al., 2010). Interestingly, the authors showed that rats unable to acquire extinction exhibit reduced BDNF levels in infralimbic cortex while reinstatement of BDNF levels overcomes extinction failure. In short, BDNF in prefrontal cortex plays a dual role depending on the cortical region involved: in the prelimbic region BDNF is required for fear memory consolidation and expression, while infralimbic BDNF is necessary for fear memory extinction. Medial prefrontal cortex BDNF is also important for memory of learned fear. Using a selective neocortical knockout mice Choi et al. (2010) found that prelimbic BDNF is important for consolidation of cued fear but not of innate fear. This impairment was rescued by DHF, a TrkB receptor agonist. Finally, epigenetic control of DNA demethylation and histone acetylation of BDNF gene in the medial prefrontal cortex appears to be important for trace fear memory retention (Sui et al., 2012).

Other cortical areas involved in BDNF-driven memory processing are: 1 - perirhinal cortex - knockdown of BDNF translation in 
this area impairs consolidation of recognition LTM (Seoane et al., 2011). 2 - Posterior parietal cortex - Alonso et al. (2005) found that BDNF in parietal cortex is involved in fear memory formation. 3 - insular cortex - a part of the temporal cortex, is a region implicated in acquisition and storage of (CTA) learning. It has been reported that BDNF activation of ERK1/2 and PI-3K signaling pathways in the insula is crucial for CTA LTM (Castillo and Escobar, 2011) and that recombinant BDNF infusion into this cortical area rescues the amnesia induced by protein synthesis inhibition (Moguel-González et al., 2008). 4 - motor cortex- the cellular mechanisms underlying learning-related plasticity in primary motor cortex (M1) depend on protein synthesis in M1 and may involve BDNF (Kleim et al., 2003). Interfering with these mechanisms induces a long-lasting loss of motor map representation. In addition, training-associated changes in fMRI measurements and in M1 excitability are down-regulated in humans carrying BDNF Val66Met polymorphism (Kleim et al., 2006). Using mouse M1 slices Fritsch et al. (2010) demonstrated that direct current stimulation, which improves motor skill learning when applied to the human M1, induces NMDA-dependent long-lasting LTP which is absent in BDNF and TrkB mutant mice, indicating that BDNF is indeed a key mediator of this phenomenon.

\section{Processing of long-lasting memory storage}

Although many studies have shed light on the mechanisms of memory consolidation during the first few hours after learning, little is known about the cellular and molecular mechanisms that continue for many hours or days to promote persistence of memory storage. Recent studies have started to address this issue, focusing mainly on the cerebral cortex as the region of permanent memory storage (Frankland and Bontempi, 2005). Few works have assessed the involvement of the hippocampus in memory persistence, probably because according to the system consolidation hypothesis, the hippocampus appears to have only a temporary role in memory storage (Zola-Morgan and Squire, 1990). A few recent papers have suggested an essential role for PKMzeta in this process. However, as mentioned earlier in this review, the finding that PKMzeta null mice do not show any memory deficits has recently challenged those results. This leaves only a handful of studies that have addressed the question of memory persistence using a different strategy. Our laboratories have focused on this issue for the past few years and found that BDNF is one of the key molecules involved in persistence of memory storage by controlling a late memory consolidation phase in the hippocampus (Bekinschtein et al., 2007). In the first of a series of studies we were able to show that a late protein synthesis-dependent phase, around $12 \mathrm{~h}$ after training, is required for IA memory persistence at 7 days, but not at 2 days posttraining. We also showed that BDNF was one of these proteins, since blocking its activity or expression $12 \mathrm{~h}$ posttraining causes a similar pattern of amnesia. Blocking protein synthesis at $12 \mathrm{~h}$ also prevents an increase in BDNF protein around this time point. We were able to demonstrate that BDNF is essential for this mechanism, since infusion of recombinant human BDNF rescues memory persistence from the effect of protein synthesis inhibition at $12 \mathrm{~h}$ post-training (Bekinschtein et al., 2008). BDNF seems to exert its action on memory persistence exclusively through the ERK1/2 signaling cascade. Thus, infusion of BDNF antisense oligonucleotides blocks ERK2 activation $12 \mathrm{~h}$ after training and inhibition of this pathway $12 \mathrm{~h}$ post-training produces amnesia at 7, but not 2 days after acquisition (Bekinschtein et al., 2008). Inhibition of mTOR, Akt and PLC-gamma signaling pathways $12 \mathrm{~h}$ after training has no effect on memory retention at 2 or 7 days, suggesting that BDNF solely activates ERK1/2 at this time point. What are the downstream targets of BDNF for memory persistence? We identified two immediate-early genes that show increased expression between 12 and $24 \mathrm{~h}$ after training, namely cFos and Zif268 (also known as egr-1; Bekinschtein et al., 2007; Katche et al., 2010, 2012). The increases in c-Fos and Zif268 proteins $24 \mathrm{~h}$ after training are blocked by inhibiting BDNF activity $12 \mathrm{~h}$ post-training (Bekinschtein et al., 2007), indicating that these two genes are downstream targets of BDNF. In addition, blockade of the late post-training expression of c-Fos and Zif268 hinders memory persistence at 7 days without affecting 2-day old memories (Katche et al., 2010, 2012). Regarding the signals that control BDNF expression required for memory persistence, several neurotransmitter systems have been identified. Recent work from our labs points to the dopaminergic system as one of the key players involved in the control of memory persistence. Shortly, intra-CA1 infusion of the D1/D5 antagonist SCH23390 $12 \mathrm{~h}$ after training produces amnesia in a test performed 2 weeks after IA training, but not 2 days post-training (Rosatto et al., 2009). This effect is reversed by co-infusion of recombinant BDNF, indicating that BDNF expression takes place after D1 receptor activation. In addition, blockade of D1 receptors prevents BDNF increase $12 \mathrm{~h}$ after training. The ventral tegmental area (VTA) was identified as one of the sources of the dopamine that is released in CA1 $12 \mathrm{~h}$ after training. NMDA receptor inactivation in the VTA late after training hindered memory 2 weeks later, but not 2 days posttraining. This effect was reversed by the D1 agonist SKF38393 and BDNF infused into the hippocampus (Rossato et al., 2009). Thus, dopamine coming from the VTA controls memory persistence through late BDNF expression in the hippocampus.

A different set of experiments implicated the serotoninergic system in the process of memory persistence (Slipczuk et al., 2013). In this study, we found that two different widely used antidepressants, fluoxetine and venlafaxine, cause amnesia 7 days, but not 2 days after IA training when injected systemically, administered via gavage $11 \mathrm{~h}$ post-training or infused locally into CA1 $12 \mathrm{~h}$ posttraining. Systemic injection of both drugs prevented the learning-related increase in BDNF $12 \mathrm{~h}$ after training, an effect reversed by intra-CA1 micro-infusion of recombinant BDNF. The observed amnesia was mediated by serotonin acting on 5HT2A receptors, since it was reversed by infusion of the 5HT2A antagonist MDL11939. Moreover, venlafaxine injection failed to reduce memory persistence in 5HT2A deficient mice. Therefore, serotonin is also one of the key players that participate in the control of memory persistence in the hippocampus, acting upstream BDNF. Other studies were able to find changes in BDNF late after training in different memory paradigms. For example, Ou and coworkers found that BDNF is increased in the amygdala $12 \mathrm{~h}$ after fear conditioning training and that inhibition of BDNF activity in this structure $12 \mathrm{~h}$ post-training impairs memory persistence (Ou et al., 2010). In a different set of experiments, Martinez-Moreno et al. (2011) showed that a late protein synthesis dependent phase is required for CTA memory maintenance in the insular cortex. Importantly, this memory impairment was reversed by recombinant BDNF infused into the same structure, indicating that BDNF is indeed essential for persistence of this kind of memory (MartinezMoreno et al., 2011). Consistent with changes in BDNF levels late after training is the recent finding that contextual fear conditioning is associated with specific modifications in hippocampal BDNF gene transcription lasting $24 \mathrm{~h}$ (Mizuno et al., 2012).

\section{Epigenetic control of BDNF gene expression and memory processing}

A great body of evidence supports a crucial role of epigeneticmediated chromatin structure regulation on memory processing (Levenson et al., 2004; Miller and Sweatt, 2007). The BDNF gene has 
a rather complex structure. It contains nine $5^{\prime}$ non-coding exons that produce many transcripts all translated into mature BDNF (Aid et al., 2007). After the demonstration that classical transcription factors such as CREB are involved in the differential expression of BDNF transcripts by an experience, attention was focused on the role of chromatin structural alterations by acetylation, methylation or phosphorylation of histone residues.

It has been suggested that changes in different histone residues of the BDNF gene promoter regions occur via activation of NMDA receptors and accompanied different behavioral trainings (Lubin, 2011). BDNF gene methylation is also an important step of epigenetic control of BDNF transcripts expression (Lubin et al., 2008). It has been shown that contextual fear conditioning results in selective expression of BDNF transcripts (exon IV), and that this is blocked by direct inhibition of DNA methylation in the dorsal hippocampus, in a NMDA receptor- and ERK-dependent manner (Levenson et al., 2004; Wood et al., 2006). In addition, it was recently demonstrated that DNA demethylation also plays an important role in LTM formation and maintenance (Day and Sweatt, 2011). DNA methylation is catalyzed by DNA methyltransferases (DNMTs). Accordingly, inhibition of DNMT within the hippocampus impairs the expression of fear memories (Lubin et al., 2008) while DNMT inhibition within the prefrontal cortex hinders remote memory retention without interfering with the consolidation of new fear memories (Miller et al., 2010). Given the role of prefrontal BDNF in fear extinction (Peters et al., 2010) it would be interesting to study whether DNA methylation or demethylation of the BDNF gene is involved in that effect. It is well known that BDNF increases dendritic spine density in an ERKdependent manner (Alonso et al., 2004). Recently, it has been suggested that histone acetylation/deacetylation is a critical step in the modulation of this process by BDNF (Calfa et al., 2012).

\section{BDNF Val66Met polymorphism}

A common single-nucleotide polymorphism (SNP) has been identified in human BDNF gene, BDNF Val66Met, which generates an alteration in trafficking BDNF and decreases BDNF local secretion which might result in impaired memory processing (Egan et al., 2003). It appears that formation and retrieval of biologically salient memories are altered in Val66Met polymorphism (van Wingen et al., 2010). On the other hand, a meta-analysis of 23 publications containing more than 7000 individuals with Val66Met polymorphism in the BDNF gene did not arrive to any firm conclusion about the cognitive impairments associated to that polymorphism (Mandelman and Grigorenko, 2012). The conflicting results in BDNF genetic studies may result from confounding factors such as age, gender, other environmental factors, sample size, ethnicity and phenotype assessment. To minimize the variability inherent to human studies, it has been recently generated a mouse model containing the BDNF Met allele that recapitulates the specific phenotypic properties of the human BDNF Val66Met polymorphism. In this mutant mouse synaptic transmission and plasticity in the infralimbic prefrontal cortex and in the hippocampus are greatly altered (Pattwell et al., 2012).

\section{Pharmacology of TrkB receptors}

Exogenous BDNF enhances memory consolidation and reconsolidation in chicks (Samartgis et al., 2012) and memory formation and persistence in different mammals (see above). In addition, recombinant BDNF and a putative TrkB agonist, the flavonoid derivative 7,8 DHF, enhance fear extinction. Given that impaired extinction occurs in anxiety disorders such as PTSD, novel agents acting via BDNF signaling may represent a new way to enhance extinction. In this context, it has been recently reported that systemic administration of 7,8 DHF enhances extinction of fear memories in mice (Andero et al., 2011). This is of particular importance since it has been previously shown that knockdown of TrkB in immature DG neurons promotes the occurrence of anxietylike behaviors and increases resistance to antidepressants (Bergami et al., 2008; Li et al., 2008). Chronic activation of TrkB by 7,8 DHF, increases spine density and number in amygdala, hippocampus and prefrontal cortex and prevents age-related decline in fear memory (Zeng et al., 2012). Consistent with these findings it has been observed that administration of 7,8 DHF can ameliorate Alzheimer's disease-associated memory deficits, which may be, at least in part, attributable to reductions in BACE1 expression and $\beta$-amyloidogenesis (Devi and Ohno, 2012).

\section{Concluding remarks}

BDNF is involved in the formation of different types of memories and is also critical for maintaining long-lasting storage of information in hippocampus, amygdala and insular cortex many hours after learning occurs. BDNF may be relevant to counteract the natural process of memory decay, which is typical in aging and is exacerbated in some neurodegenerative disorders. In this respect, over the past few years, different approaches to focally increase BDNF levels and/or function have been tested in animal models of Alzheimer's and Huntington disease. These approaches range from the use of viral vector-mediated gene transfer to the implantation of cell grafts engineered to stably express BDNF and the local delivery of ampakines, BDNF mimetics and 7,8 DHF (Pardridge, 2006; Fumagalli et al., 2006; Zuccato and Cattaneo, 2007) and, although they have been relatively successful, their technical implementation still present several serious drawbacks that need to be addressed before clinical trials are attempted.

\section{Acknowledgments}

This study was supported by research grants from the University of Buenos Aires, CONICET and the National Agency of Scientific and Technological Promotion of Argentina (ANPCyT) to JHM, and by grants from the Brazilian Council for Scientific \& Technological Development (CNPq) to $\mathrm{MC}$.

\section{References}

Adasme, T., Haeger, P., Paula-Lima, A.C., Espinoza, I., Casas-Alarcón, M.M., Carrasco, M.A., Hidalgo, C., 2011. Involvement of ryanodine receptors in neurotrophin-induced hippocampal synaptic plasticity and spatial memory formation. Proc. Natl. Acad. Sci. U. S. A. 108, 3029-3034.

Aid, T., Kazantseva, A., Piirsoo, M., Palm, K., Timmusk, T., 2007. Mouse and rat BDNF gene structure and expression revisited. J. Neurosci. Res. 85, 525-535.

Alonso, M., Vianna, M.R., Depino, A.M., Mello e Souza, T., Pereira, P., Szapiro, G. Izquierdo, I., Medina, J.H., 2002. BDNF-triggered events in the rat hippocampus are required for both short- and long-term memory formation. Hippocampus $12,551-560$.

Alonso, M., Medina, J.H., Pozzo-Miller, L., 2004. ERK 1/2 activation is necessary for BDNF to increase dendritic spine density in hippocampal CA1 pyramidal neurons. Learn. Memory 11, 172-178.

Alonso, M., Bekinschtein, P., Cammarota, M., Vianna, M.R., Izquierdo, I., Medina, J.H., 2005. Endogenous BDNF is required for long-term memory formation in the parietal cortex. Learn. Memory 12, 504-510.

Andero, R., Heldt, S.A., Ye, K., Liu, X., Armario, A., Ressler, K.J., 2011. Effect of 7,8dihydroxyflavone, a small-molecule TrkB agonist, on emotional learning. Am. J. Psychiatry $168,163-172$.

Arthur, J.S., Fong, A.L., Dwyer, J.M., Davare, M., Reese, E., Obrietan, K., Impey, S., 2004. Mitogen- and stress-activated protein kinase 1 mediates cAMP response element-binding protein phosphorylation and activation by neurotrophins. J. Neurosci. 24, 4324-4332.

Barnes, P., Thomas, K.L., 2008. Proteolysis of proBDNF is a key regulator in the formation of memory. PLoS One 24, e3248.

Bekinschtein, P., Cammarota, M., Igaz, L.M., Bevilaqua, L.R., Izquierdo, I., Medina, J.H., 2007. Persistence of long-term memory storage requires a late protein synthesis- and BDNF-dependent phase in the hippocampus. Neuron 53, 261-277. 
Bekinschtein, P., Cammarota, M., Katche, C., Slipczuk, L., Rossato, J.I., Goldin, A., Izquierdo, I., Medina, J.H., 2008. BDNF is essential to promote persistence of long-term memory storage. Proc. Natl. Acad. Sci. U. S. A. 105, 2711-2716.

Bergami, M., Rimondini, R., Santi, S., Blum, R., Götz, M., Canossa, M., 2008. Deletion of TrkB in adult progenitors alters newborn neuron integration into hippocampal circuits and increases anxiety-like behaviour. Proc. Natl. Acad. Sci. U. S. A. $105,15570-15575$.

Bozon, B., Kelly, A., Josselyn, S.A., Silva, A.J., Davis, S., Laroche, S., 2003. MAPK, CREB and zif-268 are all required for the consolidation of recognition memory. Philos. Trans. R. Soc. Lond. B. Biol. Sci. 358, 805-814

Bramham, C.R., 2008. Local protein synthesis, actin dynamics, and LTP consolidation. Curr. Opin. Neurobiol. 18, 524-531.

Bramham, C.R., Messaudi, E., 2005. BDNF function in adult synaptic plasticity: the synaptic consolidation hypothesis. Prog. Neurobiol. 76, 99-125.

Calfa, G., Chapleau, C.A., Campbell, S., Inoue, T., Morse, S.J., Lubin, F.D., PozzoMiller, L., 2012. HDAC activity is required for BDNF to increase quantal neurotransmitter release and dendritic spine density in CA1 pyramidal neurons. Hippocampus 22, 1493-1500.

Callaghan, C.K., Kelly, A.M., 2012. Differential BDNF signaling in DG and perirhinal cortex during consolidation of recognition memory in the rat. Hippocampus 22, 2127-2135.

Castillo, D.V., Escobar, M.L., 2011. A role for MAPK and PI-3K signaling pathways in brain-derived neurotrophic factor modification of conditioned taste aversion retention. Behav. Brain Res. 217, 248-252.

Choi, D.C., Maguschak, K.A., Ye, K., Jang, S.W., Myers, K.M., Ressler, K.J., 2010. Prelimbic cortical BDNF is required for memory of learned fear but not extinction or innate fear. Proc. Natl. Acad. Sci. U. S. A. 107, 2675-2680.

Cunha, C., Brambilla, R., Thomas, K.L., 2010. A simple role for BDNF in learning and memory? Front. Mol. Neurosci. 3, 1-14.

Day, J.J., Sweatt, J.D., 2011. Epigenetic mechanisms of cognition. Neuron 70, 813829

Devi, L., Ohno, M., 2012. 7,8-dihydroxyflavone, a small-molecule TrkB agonist, reverses memory deficits and BACE1 elevation in a mouse model of Alzheimer's disease. Neuropsychopharmacology 37, 434-444.

Egan, M.F., Kojima, M., Callicott, J.H., Goldberg, T.E., Kolachara, B.S., Bertolino, A., Zatsev, E., Gold, E., Goldman, D., et al., 2003. The BDNF val66met polymorphism affects activity-dependent secretion of BDNF and human memory and hippocampal function. Cell 112, 257-269.

Frankland, P.W., Bontempi, B., 2005. The organization of recent and remote memories. Nat. Neurosci. 6, 119-130.

Fritsch, B., Reis, J., Martinowich, K., Schambra, H.M., Ji, Y., Cohen, L.G., Lu, B., 2010 Direct current stimulation promotes BDNF-dependent synaptic plasticity: potential implications for motor learning. Neuron 66, 198-204.

Fumagalli, F., Racagni, G., Riva, M.A., 2006. Shedding light into the role of BDNF in the pharmacotherapy of Parkinson's disease. Pharmacogenomics J. 6, 95-104.

Furini, C.R., Rossato, J.I., Bitencourt, L.L., Medina, J.H., Izquierdo, I., Cammarota, M., 2010. Beta-adrenergic receptors link NO/sGC/PKG signaling to BDNF expression during the consolidation of object recognition long-term memory. Hippocampus $20,672-683$.

Greenberg, M., Xu, B., Lu, B., Hempstead, B.L., 2009. New insights in the biology of BDNF synthesis and release: implications in CNS function. J. Neurosci. 29, 12764-12767.

Heldt, S.A., Stanek, L., Chhatwal, J.P., Ressler, K.J., 2007. Hippocampus-specific deletion of BDNF in adult mice impairs spatial memory and extinction of aversive memories. Mol. Psychiatry 12, 656-670.

Huang, E.J., Reichardt, L.F., 2001. Neurotrophins: roles in neuronal development and function. Annu. Rev. Neurosci. 24, 677-736.

Huang, E.J., Reichardt, L.F., 2003. Trk receptors: roles in neuronal signal transduction. Annu. Rev. Biochem. 72, 609-642.

Kalita, K., Kharebava, G., Zheng, J.J., Hetman, M., 2006. Role of megakaryoblastic acute leukemia-1 in ERK1/2-dependent stimulation of serum response factordriven transcription by BDNF or increased synaptic activity. J. Neurosci. 26, $10020-10032$

Kandel, E.R., 2001. The molecular biology of memory storage: a dialog between genes and synapses. Science 294, 1030-1038.

Kang, H., Schuman, E.M., 1995. Long-lasting neurotrophin-induced enhancement of synaptic transmission in the adult hippocampus. Science 267, 1658-1662.

Karpova, N.N., Pickenhagen, A., Lindholm, J., Tiraboschi, E., Kulesskaya, N., Agústsdóttir, A., Antila, H., Popova, D., Akamine, Y., Bahi, A., Sullivan, R., Hen, R. Drew, L.J., Castrén, E., 2011. Fear erasure in mice requires synergy between antidepressant drugs an extinction training. Science 334, 1731-1735.

Katche, C., Bekinschtein, P., Slipcsuk, L., Goldin, A., Cammarota, M., Izquierdo, I. Medina, J.H., 2010. Delayed wave of c-fos expression in the dorsal hippocampus involved specifically in persistence of LTM storage. Proc. Natl. Acad. Sci. U. S. A. $107,349-354$

Katche, C., Goldin, A., Gonzalez, C., Bekinschtein, P., Medina, J.H., 2012. Maintenance of long-term memory storage is dependent on late postraining Egr-1 expression. Neurobiol. Learn. Mem. 98, 220-227.

Kelleher 3rd, R.J., Govindarajan, A., Jung, H.Y., Kang, H., Tonegawa, S., 2004. Translational control by MAPK signaling in long-term synaptic plasticity and memory. Cell 116, 467-479.

Kirtley, A., Thomas, K.L., 2010. The exclusive induction of extinction is gated by BDNF. Learn. Memory 17, 612-616.

Kleim, J.A., Bruneau, R., Calder, K., Pocock, D., VanderBerg, P.M., MacDonald, E., Monfils, M.H., Suhterland, R.J., Nader, K., 2003. Functional organization of adult motor cortex is dependent upon continued protein synthesis. Neuron 40, $167-$ 176.

Kleim, J.A., Chan, S., Pringle, E., Schallet, K., Procaccio, V., Jimenez, R., Cramer, S.C. 2006. BDNF val66met polymorphism is associated with modified experiencedependent plasticity in human motor cortex. Nat. Neurosci. 9, 735-737.

Korte, M., Carroll, P., Wolf, E., Brem, G., Thoenen, H., Bonhoeffer, T., 1995. Hippocampal long-term potentiation is impaired in mice lacking brain-derived neurotrophic factor. Proc. Natl. Acad. Sci. U. S. A. 92, 8856-8860.

Kuczewski, N., Porcher, C., Gaiarsa, J.L., 2010. Activity-dependent dendritic secretion of brain-derived neurotrophic factor modulates synaptic plasticity. Eur. J. Neurosci. 32, 1239-1244.

Lai, K.O., Wong, A.S., Cheung, M.C., Xu, P., Liang, Z., Lok, K.C., Xie, H., Palko, M.E. Yung, W.H., Tessarollo, L., Cheung, Z.H., Ip, N.Y., 2012. TrkB phosphorylation by Cdk5 is required for activity-dependent structural plasticity and spatial memory. Nat. Neurosci. 15, 1506-1515.

Levenson, J.M., O’Riordan, K.J., Brown, K.D., Trinh, M.A., Molfese, D.F., Sweatt, J.D. 2004. Regulation of histone acetylation during memory formation in the hippocampus. J. Biol. Chem. 279, 40545-40559.

Lee, A.M., Kanter, B.R., Wang, D., Lim, J.P., Zou, M.E., Qiu, C., McMahon, T., Dadgar, J. Fischbach-Weiss, S.C., Messing, R.O., 2013. Prkcz null mice show normal learning and memory. Nature. http://dx.doi.org/10.1038/nature11803.

Li, Y., Luikart, B.W., Birnbaum, S., Chen, J., Kwon, C.H., Kernie, S.G., Bassel-Duby, R., Parada, L.F., 2008. TrkB regulates hippocampal neurogenesis and governs sensitivity to antidepressive treatment. Neuron 59, 399-412.

Liao, L., Pilotte, J., Xu, T., Wong, C.C., Edelman, G.M., Vanderklish, P., Yates 3rd, J.R., 2007. BDNF induces widespread changes in synaptic protein content and upregulates components of the translation machinery: an analysis using highthroughput proteomics. J. Proteome Res. 6, 1059-1071.

Lu, B., Wang, K.H., Nose, A., 2009. Molecular mechanisms underlying neural circuit formation. Curr. Opin. Neurobiol. 19, 162-167.

Lu, Y., Christian, K., Lu, B., 2008. BDNF: akey regulator of protein synthesisdependent LTP and long-term memory? Neurobiol. Learn. Mem. 89, 312-323.

Lubin, F.D., 2011. Epigenetic gene regulation in the adult mammalian brain: multiple roles in memory formation. Neurobiol. Learn. Mem. 96, 68-78.

Lubin, F.D., Roth, T.L., Sweatt, J.D., 2008. Epigenetic regulation of BDNF gene transcription in the consolidation of fear memory. J. Neurosci. 28, 10576-10586.

Ma, L., Wang, D.D., Zhang, T.Y., Yu, H., Wang, Y., Huang, S.H., Lee, F.S., Chen, Z.Y., 2011 Region-specific involvement of BDNF secretion and synthesis in conditioned taste aversion memory formation. J. Neurosci. 31, 2079-2090.

Mahan, A.L., Ressler, K.J., 2012. Fear conditioning, synaptic plasticity and the amygdala: implications for posttraumatic stress disorder. Trends Neurosci. 35 , 25-35.

Mandelman, S.D., Grigorenko, E.L., 2012. BDNF Val66Met and cognition: all, none, or some? A meta-analysis of the genetic association. Genes Brain Behav.11,127-136.

Martinez-Moreno, A., Rodriguez-Duran, L.F., Escobar, M.L., 2011. Late proteinsynthesis-dependent phases in CTA long-term memory: BDNF requirement. Front. Behav. Neurosci. 5, 61.

McDowell, K.A., Hutchinson, A.N., Wong-Goodrich, S.J., Presby, M.M., Su, D. Rodriguiz, R.M., Law, K.C., Williams, C.L., Wetsel, W.C., West, A.E., 2010. Reduced cortical BDNF expression and aberrant memory in Carf knock-out mice. J. Neurosci. 30, 7453-7465.

Mei, F., Nagappan, G., Ke, Y., Sacktor, T.C., Lu, B., 2011. BDNF facilitates L-LTP maintenance in the absence of protein synthesis through PKMzeta. Plos One 6 e21568.

Miller, C.A., Sweatt, J.D., 2007. Covalent modifications of DNA regulate memory formation. Neuron 53, 857-869.

Miller, C.A., Gavin, C.F., White, J.A., Parrish, R.R., Honasoge, A., Yancey, C.R., Rivera, I.M., Rubio, M.D., Rumbaugh, G., Sweatt, J.D., 2010. Cortical DNA methylation maintains remote memory. Nat. Neurosci. 13, 664-666.

Minichiello, L., 2009. TrkB signaling pathways in LTP and learning. Nat. Rev. Neurosci. $10,850-860$

Mizuno, K., Dempster, E., Mill, J., Giese, K.P., 2012. Long-lasting regulation of hippocampal BDNF gene transcription after contextual fear conditioning. Genes Brain Behav. 11, 651-659.

Moguel-González, M., Gómez-Palacio-Schjetnan, A., Escobar, M.L., 2008. BDNF reverses the CTA memory deficits produced by inhibition of protein synthesis. Neurobiol. Learn. Mem. 90, 584-587.

Murer, M.G., Yan, Q., Raisman-Vosari, R., 2001. BDNF in the control human brain, and in Alzheimer's disease and Parkinson's disease. Prog. Neurobiol. 63, 71-124.

Ou, L.C., Yeh, S.H., Gean, P.W., 2010. Late expression of brain-derived neurotrophic factor in the amygdala is required for persistence of fear memory. Neurobiol. Learn. Mem. 93, 372-382.

Pardridge, W.M., 2006. Molecular trojan horses for blood-brain barrier drug delivery. Discov. Med. 6, 139-143.

Pang, P.T., Lu, B., 2004. Regulation of late phase LTP in normal and aging hippocampus: role of secreted protein tPA and BDNF. Ageing Res. Rev. 3, 407-430.

Pattwell, S.S., Bath, K.G., Perez-Castro, R., Lee, F.S., Chao, M.V., Ninan, I., 2012. The BDNF Val66Met polymorphism impairs synaptic transmission and plasticity in the infralimbic medial prefrontal cortex. J. Neurosci. 32, 2410-2421.

Peters, J., Dieppa-Perea, L.M., Melendez, L.M., Quirk, G.J., 2010. Induction of fear extinction with hippocampal-infralimbic BDNF. Science 328, 1288-1290.

Poo, M.-M., 2001. Neurotrophins as synaptic modulators. Nat. Rev. Neurosci. 2, 24-32.

Ramanan, N., Shen, Y., Sarsfield, S., Lmbeger, T., Schultz, G., Linden, D.J., Ginty, D.D. 2005. SRF mediates activity-induced gene expression and synaptic plasticity but not neuronal viability. Nat. Neurosci. 8, 759-767. 
Rattiner, L.M., Davis, M., Ressler, K.J., 2005. Brain-derived neurotrophic factor in amygdala-dependent learning. Neuroscientist 11, 323-333.

Riccio, A., Alvania, R.S., Lonze, B.E., Ramanan, N., Kim, T., Huang, Y., Dawson, T.M. Snyder, S.H., Ginty, D.D., 2006. A nitric oxide signaling pathway controls CREBmediated gene expression in neurons. Mol. Cell. 21, 283-294.

Rossato, J., Bevilaqua, L., Izquierdo, I., Medina, J.H., Cammarota, M., 2009. Dopamine controls the persistence of long-term memory storage. Science 325, 1017-1020.

Sacktor, T.C., 2011. How does PKMzeta maintain long-term memory? Nat. Rev. Neurosci. 12, 9-15.

Sacktor, T.C., Osten, P., Valsamis, H., Jiang, X., Naik, M.U., Sublette, E., 1993. Persistent activation of the zeta isoform of PKC in the maintenance of long-term potentiation. Proc. Natl. Acad. Sci. U. S. A. 90, 8342-8346.

Samartgis, J.R., Schachte, L., Hazi, A., Crowe, S.F., 2012. BDNF facilitates memory consolidation and reconsolidation of a weak training stimulus in the day-old chick. Neurosci. Lett. 516, 119-123.

Schratt, G.M., Nigh, E.A., Chen, W.G., Hu, L., Greenberg, M.E., 2004. BDNF regulates the translation of a select group of mRNAs by a mammalian target of rapamycin-phosphatidylinositol 3-kinase-dependent pathway during neuronal development. J. Neurosci. 24, 7366-7377.

Sharma, S.K., Sherff, C.M., Stough, S., Hsuan, V., Carew, T.J., 2006. A tropomyosinrelated kinase $B$ ligand is required for ERK activation, long-term synaptic facilitation, and long-term memory in Aplysia. Proc. Natl. Acad. Sci. U. S. A. 103 14206-14210.

Seoane, A., Tinsley, C.J., Brown, M.W., 2011. Interfering with perirhinal brain-derived neurotrophic factor expression impairs recognition memory in rats. Hippocampus 21, 121-126.

Slipczuk, L., Bekinschtein, P., Katche, C., Cammarota, M., Izquierdo, I., Medina, J.H., 2009. BDNF activates mTOR to regulate GluR1 expression required for memory formation. Plos One 4, e6007.

Slipczuk, L., Tomaiuolo, M., Garagoli, F., Weisstaub, N., Katche, C., Bekinschtein, P. Medina, J.H., 2013. Attenuating the persistence of fear memory storage by a single dose of antidepressant. Mol. Psychiatry 18 (1), 7-8.
Soule, J., Messaoudi, E., Bramham, C.R., 2006. Brain-derived neurotrophic factor and control of synaptic consolidation in the adult brain. Biochem. Soc. Trans. 34 600-604.

Sui, L., Wang, Y., Ju, L.H., Chen, M., 2012. Epigenetic regulation of reelin and brainderived neurotrophic factor genes in long-term potentiation in rat medial prefrontal cortex. Neurobiol. Learn. Mem. 97, 425-440.

Tyler, W.J., Alonso, M., Bramham, C.R., Pozzo-Miller, L.D., 2002. From acquisition to consolidation: on the role of brain-derived neurotrophic factor signaling in hippocampal-dependent learning. Learn. Memory 9, 224-237.

van Wingen, G., Rijpkema, M., Franke, B., van Eijndhoven, P., Tendolkar, I., Verkes, R.J., Buitelaar, J., Fernández, G., 2010. The brain-derived neurotrophic factor Val66Met polymorphism affects memory formation and retrieval of biologically salient stimuli. Neuroimage 50, 1212-1218.

Volk, L.J., Bachman, J.L., Johnson, R., Yu, Y., Huganir, R.L., 2013. PKM- $\zeta$ is not required for hippocampal synaptic plasticity, learning and memory. Nature. http:// dx.doi.org/10.1038/nature11802.

Wood, M.A., Hawk, J.D., Abel, T., 2006. Combinatorial chromatin modifications and memory storage: a code for memory? Learn. Memory 13, 241-244.

Yin, Y., Edelman, G.M., Vanderklish, P.W., 2002. The brain-derived neurotrophic factor enhances synthesis of Arc in synaptoneurosomes. Proc. Natl. Acad. Sci. U. S. A. 99, 2368-2372

Ying, S.W., Futter, M., Rosenblum, K., Webber, M.J., Hunt, S.P., Bliss, T.V., Bramham, C.R., 2002. Brain-derived neurotrophic factor induces long-term potentiation in intact adult hippocampus: requirement for ERK activation coupled to CREB and upregulation of Arc synthesis. J. Neurosci. 22, 1532-1540.

Zeng, Y., Liu, Y., Wu, M., Liu, J., Hu, Q., 2012. Activation of TrkB by 7,8 DHT prevents fear memory defects and facilitates amygdalar synaptic plasticity in aging. J. Alzheimers Dis. 31, 765-778.

Zola-Morgan, S.M., Squire, L.R., 1990. The primate hippocampal formation: evidence for a time-limited role in memory storage. Science 250, 288-290.

Zuccato, C., Cattaneo, E., 2007. Role of brain-derived neurotrophic factor in Huntington's disease. Prog. Neurobiol. 81, 294-330. 